\title{
Antioxidant Activity Assay of Alpha-mangostin for Amelioration of Kidney Structure and Function in Diabetic Mice
}

\author{
Saikhu Akhmad Husen ${ }^{*}, 1,2$, Salamun ${ }^{1}$, Firas Khaleyla ${ }^{1,2}$, Arif Nur Muhammad Ansori ${ }^{3}$, Raden Joko Kuncoroningrat \\ Susilo $^{1}$, Dwi Winarni ${ }^{1,2}$ \\ ${ }^{1}$ Department of Biology, Faculty of Science and Technology Universitas Airlangga \\ ${ }^{2}$ Animal Histology Laboratory, Faculty of Science and Technology Universitas Airlangga \\ ${ }^{3}$ Faculty of Veterinary Medicine Universitas Airlangga \\ Kampus C Universitas Airlangga, 60115, Surabaya, Indonesia \\ *e-mail: saikhuakhmad1408@gmail.com
}

\begin{abstract}
This research was aimed to investigate the ability of a alpha-mangostin compound derived from mangosteen pericarp to reduce plasma blood urea nitrogen (BUN) and creatinine level, and also to ameliorate the damaged renal proximal tubular of the kidneys in diabetic mice. An in-vivo antioxidant test was conducted using male BALB/c mice. The mice were divided into two groups; normal control (KN) and streptozotocin-induced diabetic mice. Streptozotocin (STZ) induction was performed using multiple low-doses of $30 \mathrm{mg} / \mathrm{kg}$ injected for five consecutive days. The diabetic mice were separated again into three sub-groups; diabetic control (KD), diabetic mice treated with Metformin $\mathrm{HCl}(\mathrm{KM})$, and diabetic mice treated with alpha-mangostin. The alpha-mangostin treatment group was categorised based on the dose given; P1 (2 $\mathrm{mg} / \mathrm{kg}$ body weight), P2 (4 mg/kg body weight) and $P 3(8 \mathrm{mg} / \mathrm{kg}$ body weight). Before and after STZ injection, the body weight and fasting blood glucose were measured. The body weight and fasting blood glucose were measured on the $1^{\text {st }}, 7^{\text {th }}$, and $14^{\text {th }}$ day of alpha-mangostin treatment. Alpha-mangostin was given orally for 14 days. On the $15^{\text {th }}$ day, the plasma BUN and creatinine level were measured using Pentra $C 200$. Interestingly, the administration of alpha-mangostin was able to lower the plasma BUN and creatinine level, and also the ameliorate-damaged renal proximal tubular epithelial cells of the kidney in diabetic mice leseened significantly.
\end{abstract}

Keywords-alpha-mangostin, blood urea nitrogen, diabetic mice, plasma creatinine, renal proximal tubular of kidney

\section{INTRODUCTION}

Diabetes mellitus (DM) is a global health problem with a high level of morbidity and mortality [1]. More than 380 million people in the worldwide suffered from DM in 2015 and this will be estimated to rise up to 592 million people in 2025. Indonesia has reached the fourth rank in the world which has 15.4 million diabetes mellitus patients in 2012. This will be estimated to rise up to 21.3 million people in 2020 . $\mathrm{DM}$ is a chronic pancreatic metabolic disorder, which is indicated by a high level of hyperglycemia and the disruption of carbohydrate, fat, and protein metabolism [2, 3]. Hyperglycemia in DM patients can cause glucose auto- oxidation, the activation of protein glycation, and the activation of polyol metabolism pathways which will accelerate the reactive oxygen species (ROS) or oxidative stress condition. ROS within the body will elevate free radicals. Free radicals are able to damage various tissues in the body, including renal proximal tubular tissue [4].

Diabetes-induced damage on the renal tissue includes glomeruli hypertrophy, glomeruloschlerosis, swelling, apoptosis, and the necrosis of the tubule epithelium [5]. The damage to the renal proximal tubular epithelial cells is also one of the morphological changes found in the kidneys of diabetes patients [6]. Blood urea nitrogen (BUN) and creatinine excretion result from two physiological processes; glomerular filtration and the secretion of renal proximal tubular epithelial cells [7]. Creatinine is a keratin metabolite, while BUN is a waste product in blood circulation resulting from protein metabolism. Creatinine and urea nitrogen are synthesised mainly in the liver and kidney, and are found in almost all parts of skeletal muscle bound as phosphate creatine [8]. The disruption of BUN and creatinine secretion at the renal proximal tubules will result in rising plasma BUN and creatinine level. This is due to the damage on the glomerulus, leading to a lowering of glomerular filtration rate (GFR) followed by rising plasma BUN and creatinine level [9].

Mangosteen contains various antioxidative compounds such as xanthone, terpene, anthocyanin, tannin, phenol, and several vitamins. Xanthone is derived from mangosteen pericarp, such as alpha-mangostin, gamma-mangostin, garsinon, mangostanol, and beta-mangostin [10]. Antioxidants are a substance able to muffle the negative effects of free radicals by means of donor electrons, thus making them able to ameliorate damage on the lipids, cell membrane, blood vessels, DNA and other cellular components caused by reactive compounds such as ROS. In order to reduce the negative effect of free radicals, exogenic antioxidative agents are required, such as vitamin $\mathrm{E}$, vitamin $\mathrm{C}$, and other antioxidants obtained from consuming various fruits and vegetables with high-antioxidant contents. One of the antioxidants which is expected to be able to muffle free 
radicals is alpha-mangostin. Alpha-mangostin is a pigment compound of Garcinia mangostana L. that is able to donate the hydrogen atom and to stabilise free radicals resonantly. In addition to neutralising free radicals, this antioxidant is also expected to be able to lower oxidative stress, mainly in the various cells affected by extended hyperglycemia, such as the hepatocytes in liver and kidney tubule cells [11].

The aim of this study is to prove that alpha-mangostin is able to lower plasma BUN and creatinine level, and that it also ameliorates damaged renal proximal tubular epithelial cells in diabetic mice. This study is also expected to improve the quality of life of DM patients by utilising local natural resources, particularly in mangosteen which has potential as an antioxidant for medicine and in the treatment of some metabolic and degenerative diseases.

\section{MATERIAL AND METHODS}

This study was an experimental study conducted in the Animal Laboratory and Animal Histology Laboratory in the Faculty of Science and Technology of the Universitas Airlangga. The samples used were adult male mice (Mus musculus) strain BALB/C age 4-5 months, weighted 30-40 g. The materials used were alpha-mangostin powder obtained from SIGMA (> 98\% (HPLC), No. Cat. M3824-50MG), streptozotocin (STZ) for inducing diabetes in mice obtained from SIGMA (No. Cat. S0130-1G), buffer citrate solution $\mathrm{pH}$ 4.5, phosphate-buffered saline (PBS), carboxymethylcellulose (CMC) for solvent, standard anti-diabetic remedy (Metformin $\mathrm{HCl} 100 \mathrm{mg} / \mathrm{kg}$ body weight), lard, anaesthesia (xylazine and ketamine) and glucose (10\% D-glucose dissolved in distilled water). The main instruments used in this study were mice pens consisting of a plastic container with a wire net covering, drinking bottle, feeder, husk, and a light microscope. Also used were a petri dish, an analytical balance with a precision of 6 numbers behind the comma, injection needles with lead safety tips, $1 \mathrm{~mL}$ insulin injection syringes for diabetes induction, Accu-Chek ${ }^{\circledR}$ Active blood glucometer, Easytouch Cholesterol Test, and glass instruments [12].

The sample consisted of 24 male mice, divided into a normal control $(\mathrm{KN})$ and diabetes group (induced by STZ). Each mouse had its body weight and blood cholesterol level recorded before and after lard administration, then the diabetes group was injected with STZ. The blood glucose level was noted on the 7th and 14th day after STZ induction using a glucometer to determine the diabetes level in the mice. Only mice with a blood glucose level above $170 \mathrm{mg} / \mathrm{dL}$ were used as diabetic mice in this study. The mice were then grouped as follows; the non-diabetic mice were grouped as the normal control (KN), while the STZ-induced diabetic mice were further divided into the diabetic control (KD), diabetic control treated with $100 \mathrm{mg} / \mathrm{kg}$ body weight Metformin $\mathrm{HCl}(\mathrm{KM})$, and the alpha-mangostin treatment group. The Alphamangostin group were separated based on the dose given; P1 ( $2 \mathrm{mg} / \mathrm{kg}$ body weight), P2 (4 mg/kg body weight) and P3 (8 $\mathrm{mg} / \mathrm{kg}$ body weight). Each group consisted of 4 mice. Alphamangostin was given orally for 14 days. On the 15th day, intracardiac blood was collected and both the plasma BUN and creatinine level were measured based on absorbance using Pentra C200 (Horiba Medical) at a wavelength of $510 \mathrm{~nm}$
[13], while the liver was sectioned into histological slides stained with hematoxylin-eosin.

\section{RESULTS AND DISCUSSION}

The mean plasma BUN and creatinine level based on the absorbance measurement after alpha-mangostin administration on the 15th day has been presented in Fig 1. The mean of the histological evaluation resulted in swollen and necrotic renal proximal tubular epithelial cells after alpha-mangostin administration on the $15^{\text {th }}$ day as presented in Fig 2 . The histological section of the kidney after alpha-mangostin treatment has been presented in Fig 3.
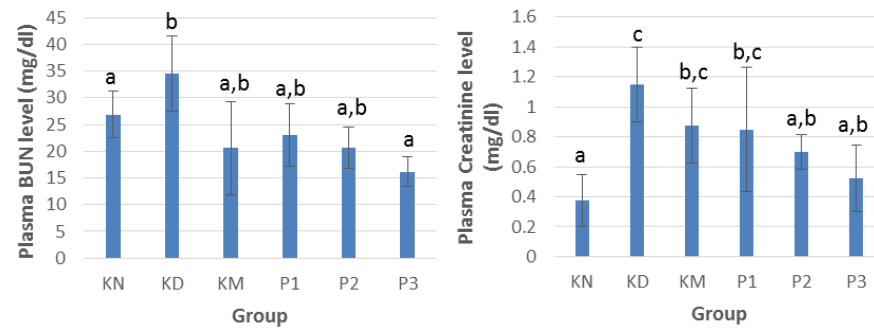

Figure 1 (above). Graphic showing the effects of alphamangostin administration on plasma BUN and creatinine level in diabetic mice. $\mathrm{KN}$ : normal control, $\mathrm{KD}$ : untreated diabetic control, KM: diabetic control treated with $100 \mathrm{mg} / \mathrm{kg}$ body weight Metformin $\mathrm{HCl}, \mathrm{P} 1$ : diabetic mice given $2 \mathrm{mg} / \mathrm{kg}$ body weight alpha-mangostin, P2: diabetic mice given $4 \mathrm{mg} / \mathrm{kg}$ body weight alpha-mangostin, P3: diabetic mice given 8 $\mathrm{mg} / \mathrm{kg}$ body weight alpha-mangostin. Letters above the bar indicate the results of the Duncan test $(\alpha=0.05)$. The same letter indicates no significant difference, and a different letter indicates a significant difference.

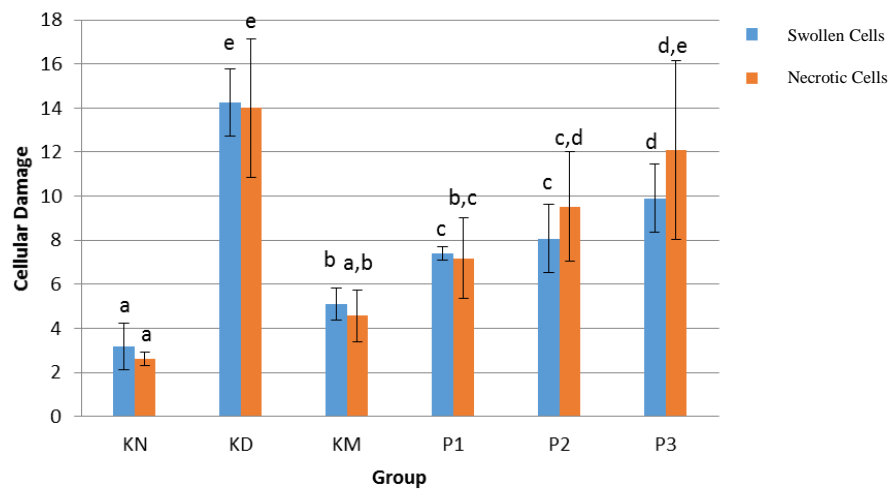

Figure 2. (above) Graphic showing effect of alpha-mangostin administration on renal proximal tubular epithelial cells of diabetic mice. KN: normal control, KD: untreated diabetic control, KM: diabetic control treated with $100 \mathrm{mg} / \mathrm{kg}$ body weight Metformin $\mathrm{HCl}, \mathrm{P} 1$ : diabetic mice given $2 \mathrm{mg} / \mathrm{kg}$ body weight alpha-mangostin, P2: diabetic mice given $4 \mathrm{mg} / \mathrm{kg}$ body weight alpha-mangostin, P3: diabetic mice given 8 $\mathrm{mg} / \mathrm{kg}$ body weight alpha-mangostin. The letters above the bar indicate the results of the Duncan test $(\alpha=0.05)$. The same 
letter indicates no significant difference, and a different letter indicates a significant difference.

Hyperglycemia causes glucose to be unable to be processed into energy, thus the energy was processed from other sources such as fat and protein [14]. Hyperglycemia in DM patients causes glucose autoxidation, leading to the activation of protein kinase $\mathrm{C}$, protein glycation, and the activation of the polyol pathway that accelerates the formation of ROS or oxidative stress. ROS causes the elevation of the free radical level within the body. Free radicals could damage the structure and function of various tissues, including renal tissue [4]. Histopathological damage on the structure and function of renal tissue has been previously reported as glomeruli hypertrophy, glomeruschlerosis, and swelling, apoptosis, and the necrosis of renal proximal tubular epithelial cells [5]. In DM patients, hyperglycemia can increase the level of ROS and RNS due to the elevation of NADPH oxidation in endothelium tissue. ROS and Reactive Nitrogen Species (RNS) are highly reactive molecules able to oxidize directly and in to damaged DNA, proteins and lipid, and also increases the oxidative stress level. Oxidative stress occurs when imbalance happens between highly reactive molecules (ROS and RNS) with existing antioxidants [3].

STZ is a type of highly reactive free radical able to elevate ROS and RNS levels, mainly in the hepatocytes and renal proximal tubular epithelial cells. In the STZ-induced diabetic mice, the plasma BUN and creatinine were found to be increased; mainly in $\mathrm{KD}$, a significant difference was found statistically towards KN, KM, P1, P2, and P3. This was due to the diabetic-induced ROS formation through glucose autooxidation, advanced glycation end product (AGEs) formation and the polyol pathway mechanism. ROS was able to stimulate lipid peroxidation in the cell membrane, thus damaging the cell itself. Free radicals damage the cell membrane structure due to lipid peroxidation, thus breakdown occurred in the structure and function of the renal proximal tubular epithelial cells, as indicated by the elevation of plasma BUN and creatinine in $\mathrm{KD}$ compared to the $\mathrm{KN}, \mathrm{KM}$, and alpha-mangostin treatment groups. This fact indicates that STZ injection at multiple low doses was able to increase plasma BUN and creatinine level significantly compared to the other groups, while the plasma creatinine of KD showed a statistically significant difference towards the normal control and all of the alpha-mangostin treatment groups.

The kidney is an organ which plays a role in regulating balance within the body, maintaining bodily fluid, and organising the discharge of metabolic waste and toxic substances such as urea, uric acid, ammonia, creatinine, inorganic salts and a number of medicinal substances not required by the body [15]. BUN and creatinine are ureal metabolites of protein and keratin excreted through glomerular filtration and actively secreted by the renal proximal tubular epithelial cells [16]. Damage in the renal proximal tubular epithelial cells was found to be a better indication of disease progressivity compared to glomerular damage. The excretion of BUN and creatinine resulted from two physiological processes; glomerulus filtration and the secretion of renal proximal tubules. If disruption occurred in BUN and creatinine secretion by way of the renal proximal tubular epithelial cells, then the plasma BUN and creatinine level would be elevated [7]. Guyton and Hall [17] stated that the plasma BUN and creatinine would be elevated to about twicefold the normal level when renal function is decreased up to 50\%. According to Panjaitan et al. [18], in renal failure, BUN and creatinine along with other non-protein nitrogen substances is retained.

Creatinine is excreted by the kidney at a relatively constant rate and is not affected by factors outside of the kidney. Creatinine is an effective indicator of kidney damage due to its stable level in plasma [17]. Rising plasma creatinine level is possibly caused by renal damage, mainly the disruption of glomerulus filtration, acute tubules necrosis, glomerulonephritis (glomerular damage) and apoptosis of the renal proximal tubular epithelial cells $[19,20]$. The normal serum creatinine level in mice (Mus musculus) is at 0.2-0.9 $\mathrm{mg} / \mathrm{dL}$ range [13]. A previous study by Parvizi et al. [21] showed that STZ-injected diabetic rats (Rattus norvegicus) had a higher serum creatinine level compared to the normal control. This was due to damage in the histological structure of the diabetic rat kidneys, thus the kidney activity in relation to eliminating creatinine was disrupted. Guyton and Hall [17] stated that the serum creatinine level would increase to twofold that of normal level if the renal function decreased to $50 \%$.

STZ is a nitrite oxide (NO) donor that played an important role in cellular damage. In addition, STZ also could activate reactive oxygen that plays an important role in cellular damage [22]. Free radicals ROS and RNS could disrupt the physiological function of various tissues and possibly caused damage in the kidney. Kim et al. [23] stated that the elevation of ROS and pro-inflammation cytokine levels played an important role in damaging glomeruli, tubules and blood vessels. Study results from Zafar et al. [24] showed that diabetic rats (Rattus norvegicus) induced with a single-dose STZ injection on a $45 \mathrm{mg} / \mathrm{kg}$ body weight dose were found to have necrosis on their tubules, glomerulosclerosis, tubular atrophy, and a thickening of the glomerular membrane. Another study done by Hou et al. [25] showed that rising the serum blood urea nitrogen (BUN) and creatinine level in the diabetic group indicated renal damage. Biochemical parameters were found to be correlated with the renal histological study. STZ, a type of highly reactive free radical, causes significant damage to the renal histological structure including glomeruli and the tubules. It also impairs the function of the renal proximal tubular epithelial cells in diabetic mice. In addition to neutralising free radicals caused by STZ, Husen [11] stated that mangosteen pericarp extract is expected to be able to lower oxidative stress, mainly in the various cells affected by extended hyperglycemia, such as hepatocytes in the liver and renal proximal tubular epithelial cells.

\section{CONCLUSION}

We concluded that the administration of alpha-mangostin was able to lower the plasma BUN and creatinine level, and also ameliorate the damaged renal proximal tubular epithelial cells of kidney in diabetic mice significantly, mainly the swollen and necrotic cells. On the other hand, the result of this 
study was expected to be material in the counselling community on the benefit of the alpha-magostin compound extracted from mangosteen pericarp for the treatment of DM, mainly in relation to ameliorating damaged kidney structure and function.

\section{ACKNOWLEDGMENT}

The authors would like to thank the Dean of the Faculty of Science and Technology and the Head of the Institute of Innovation and Research at the Universitas Airlangga for the opportunity given to conduct this research funded by DRPM DIKTI - Ministry of Research, Technology, and Higher Education 2017.

\section{REFERENCES}

1. A.C. Guyton, J.E. Hall, Buku Ajar Fisiologi Kedokteran, Edisi 12, Jakarta: Penerbit EGC, 2013.

2. A.D. Wulandari, Hubungan Dislipidemia dengan Kadar Ureum dan Kreatinin Darah pada Penderita Nefropati Diabetik, Skripsi, Semarang: Fakultas Kedokteran Universitas Diponegoro, 2012.

3. American Diabetes Association, Standards of Medical Care in Diabetes-2013. Diabetes Care. 36 (Suppl. 1), 2013, pp. S11-S66.

4. C.G. Musso, H. Michelángelo, M. Vilas, J. Reynaldi, B. Martinez, L. Algranati, N.J.F. Macías, "Creatinine reabsorption by the aged kidney," Int Urol Nephrol, 41, pp. 727-731, 2009.

5. D. Verzola, M.T. Gandolfo, F. Ferrario, M.P. Rastaldi, B Villaggio, F. Gianiorio, M. Giannoni, L. Rimoldi, F. Lauria, M. Miji, G. Deferrari, G. Garibotto, "Apoptosis in the kidneys of patients with type II diabetic nephropathy," Kidney Int., 72(10): pp. 1262-72, 2007.

6. E.J. Corwin, Buku Suku Patofisiologi, Edisi Ketiga, Jakarta: Penerbit EGC, 2009

7. E.Y. Kim, C.S. Kim, J.S. Choi, E.H. Bae, S.K. Ma, K.K. Kim, J.U. Lee, S.W. Kim, K.E. Lee, "Macrophage-stimulating protein attenuates gentamicin-induced inflammation and apoptosis in human renal proximal tubular epithelial cells," Biochem. Biophys. Res. Commun, 434, pp. 527-533.

8. F. Öztürk, M. Iraz, M. Eşrefoğlu, M. Kurus, M., Gül, A. Otlu, "The histological alterations of experimental diabetes on the rat kidneys," J Inonu Univ Med Fac, 12, pp. 1-4, 2005.

9. J. Pedraza-Chaverrí, D. Barrera, P.D. Maldonado, Y.I. Chirino, N.A. Macías-Ruvalcaba, O.N. Medina-Campos, L. Castro, M.I. Salcedo, R. Hernández-Pando, "S-allylmercaptocysteine scavenges hydroxyl radical and singlet oxygen in vitro and attenuates gentamicin-induced oxidative and nitrosative stress and renal damage in vivo," BMC Clin Pharmacol. 4:5, 2004

10. L.A. Stevens, A.S. Levey, "Clinical implications for estimating equations for glomerular filtration rate," Ann. Intern. Med, 141: pp. 959-961, 2004.
11. M.D. Breyer, Z. Qi., "Better nephrology for mice-and man," Kidney Int, 77, pp. 487-9, 2010.

12. M.R. Parvizi, M. Parviz, S.M. Tavagar, N. Soltani, M Kadkhodaee, B. Seifi, Y. Azizi, M. Keshavarz, "Protective effect of magnesium on renal function in STZ-induced diabetic rats," Journal of Diabetes \& Metabolic Disorders, 13:84, 2014.

13. M. Zafar, S.N. Naqvi, M. Ahmed, Z.A. Kaimkhani, "Altered kidney morphology and enzymes in streptozotocin induced diabetic rats," Int. J. Morphol, 27(3), 783-790, 2009.

14. N.A. Campbell, J.B. Reece, Biologi, Edisi Kedelapan, Jakarta: Penerbit Erlangga, 2012.

15. P.S.T. Yuan, S.R. Dunn, T. Miyaji, H. Yasuda, K. Sharma, R.A Star, "A simplified method for HPLC determination of creatinine in mouse serum," Am. J. Physiol. 286: pp. F1116-F1119, 2004.

16. R.G. Panjaitan, E. Handharyani, Chairul, Masriani, Z. Zakiah, W. Manalu, "Pengaruh pemberian karbon tetraklorida terhadap fungsi hati dan ginjal tikus," Jurnal Kesehatan, 11(1), pp. 11-16, 2007.

17. R.L. Hall, Clinical pathology of laboratory animals in Animal Model in Toxicology, 2nd Edition, USA: CRC Press. p. 789-828, 2007.

18. S. Hou, C. Liang, H. Liu, D. Zhu, Y. Wu, J. Liang, Y. Zhao, J. Guo, S. Huang, X. Lai, "Dendrobium officinale Prevents Early Complications in Streptozotocin-Induced Diabetic Rats," Evidence-Based Complementary and Alternative Medicine, Vol. 2016, 2016.

19. S.A. Husen, D. Winarni, "Potensi Berbagai Fraksi Ekstrak Kulit Buah Manggis (Garcinia mangostana L.) Terhadap Kadar HbA1c dan Glukosa Darah Puasa Mencit Diabetes Mellitus Tipe 2," Proceeding Seminar Nasional Biodiversitas V, Universitas Airlangga, September 2014.

20. S.A. Husen, D. Winarni, F. Khaleyla, S.H. Kalqutny, A.N.M. Ansori, "Activity Assay of Mangosteen (Garcinia mangostana L.) Pericarp Extract for Decreasing Fasting Blood Cholesterol Level and Lipid Peroxidation in Type-2 Diabetic Mice," AIP Proceedings Conference, in press.

21. S.A. Husen, D. Winarni, A.N.M. Ansori, R.J.K. Susilo, "Potensi Ekstrak Kasar Kulit Buah Manggis (Garcinia mangostana L.) Terhadap Kadar Kolesterol dan Kadar Glukosa Darah Puasa Mencit Diabetik," Proceeding Seminar nasional Biodiversitas VI, Universitas Airlangga, pp. 841-850, September 2016.

22. S.A. Husen, D. Winarni, F. Khaleyla, S.H. Kalqutny, "Activity test of various mangosteen (Garcinia mangostana) pericarp extract fractions to decrease fasting blood cholesterol levels and lipid peroxidation activity in diabetic mice," Journal of Biological Researches, 22(1), pp. 13-17, 2016.

23. S.K. Kang, W. Lee, Y. Jung, J.H. Lee, S. Lee, D. Eom, Y. Jeon, H.H. Yoo, M.J. Jin, K.I. Song, W.J. Kim, J. Ham, H.J. Kim, S Kim, "Protective Effect of Esculin on Streptozotocin-Induced Diabetic Renal Damage in Mice." J. Agric. Food Chem, 62, pp. 2069-2076, 2014. 


\section{ATLANTIS
PRESS}

24. Y. Ueno, M. Kizaki, R. Nakagiri, T. Kamiya, H. Sumi, T. Osawa, "Dietary gluthatione protects rats from diabetic nephropathy and neuropathy," J Nutr, 132: pp. 897-900, 2002.
25. Y.W. Chin, H.A. Jung, H. Chai, W.J. Keller, A.D. Kinghorn, "Xanthones with quinone reductase-inducing activity from the fruits of Garcinia mangostana (Mangosteen)," Phytochemistry, 69, pp. $754-758,2008$.
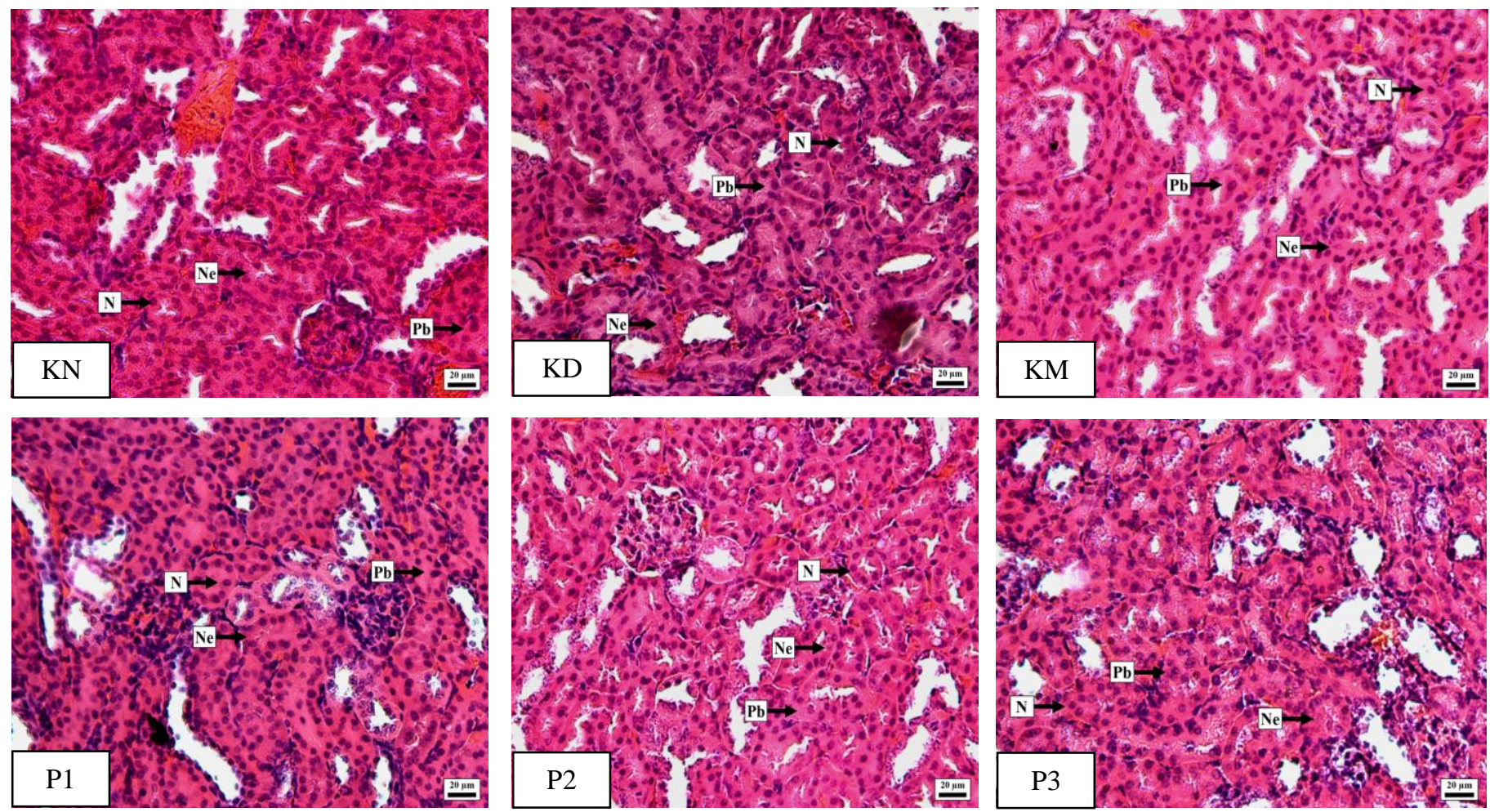

Figure 3. Histological section of kidney of diabetic mice showing damaged renal proximal tubular epithelial cells. KN: normal control, KD: untreated diabetic control, KM: diabetic control treated with $100 \mathrm{mg} / \mathrm{kg}$ body weight Metformin $\mathrm{HCl}$, P1: diabetic mice given $2 \mathrm{mg} / \mathrm{kg}$ body weight alpha-mangostin, P2: diabetic mice given $4 \mathrm{mg} / \mathrm{kg}$ body weight alpha-mangostin, P3: diabetic mice given $8 \mathrm{mg} / \mathrm{kg}$ body weight alpha-mangostin. N: normal cell, S: swollen cell, Ne: necrotic cell. Scale bar: $20 \mu \mathrm{m}$. 